\title{
Antiproliferative and apoptotic effects of black turtle bean extracts on human breast cancer cell line through extrinsic and intrinsic pathway
}

\author{
Suresh Kumar, Vinay Kumar Sharma, Savita Yadav and Sharmistha Dey ${ }^{*}$
}

\begin{abstract}
The black turtle bean (BTB) is most widely consumed legume all over the world having anticancer activity. The aim of the study was to analyse the apoptotic effects of BTB extracts on human breast cancer cell lines. Plant extract was prepared by homogenization and centrifugation. The cytotoxic effects of BTB was evaluated by MTT assay and their apoptotic effects were characterized by DNA fragmentation, nuclear staining assay, mitochondrial membrane potential analysis, annexin-V FITC and caspase 3/7 activity assay. The changes in cell cycle and gene expression of cell lines were analysed by flow cytometry and qRT-PCR, respectively. BTB extract showed cytotoxicity with $I C_{50}$ values of $50 \mathrm{\mu g} / \mathrm{ml}$ in MCF-7 and MDA-MB231 cells. The caspase 3/7 was activated in the cancer cells treated with BTB extract leading to cell death by apoptosis. Moreover, there was significant increase in the expression of Bax as well as decrease in the $\mathrm{BCl}-2$ and $\mathrm{BCl}-\mathrm{xL}$ expression with in a dose dependent manner in both cells. It induces cell cycle arrest in S and G2/M phase in MCF-7 and MDA-MB231 cells, respectively. The mitochondrial membrane potential was decreased in BTB treated cells thereby transducing the apoptotic signal through the mitochondrial pathway and it also causes DNA fragmentation. Thus, it can be concluded that BTB induces the apoptosis in MCF-7 and MDA-MB-231 cells through intrinsic and extrinsic pathway and can be explored further for promising candidate to combat breast cancer. BTB extract exhibit anti-cancer activity by inducing apoptosis in breast cancer cell lines.
\end{abstract}

Keywords: Black turtle beans (Phaseolus vulgaris) extract, Apoptosis, Caspase 3/7, AnnexinV-FITC, Cell cycle arrest, Mitochondrial membrane potential, Bcl-2 family proteins

\section{Background}

The importances of plants in primary health care have been increasingly appreciated due to the growing utilization of 'alternative' medicines. The World health organization is promoting the use of medicinal plants, given their safety, efficacy and affordability. Most plants contain natural protectants, including flavonoids, which are powerful anti-oxidants that can also chelate metals, thereby affording protection against an array of diseases and disorders. The use of medicinal plant extracts for the treatment of human diseases is an ancient practice, which has greatly

\footnotetext{
*Correspondence: sharmistha_d@hotmail.com

Department of Biophysics, All India Institute of Medical Sciences, Ansari Nagar, New Delhi 110 029, India
}

increased in recent years [1]. Natural compounds have provided many of the effective anticancer agents in current use. Over $50 \%$ of drugs used in clinical trials for anticancer activity have been isolated from natural sources or are closely related to them [2].

Black turtle beans (BTB) are a variety of common beans, belonging to the Phaseolus vulgaris $\mathrm{L}$ species of the Fabaceae family, and contain a high concentration of flavonoids. Researchers found that the darker the coat of this bean's seeds, the higher the flavonoid contents. Such phenolic compounds, widely present in plants, inhibit or attenuate the initiation, progression and spread of cancer [3]. The high antioxidant capacity of colored beans (black, navy, pinto, red kidney and small red) has been investigated by using the oxygen radical absorbance 
capacity (ORAC) assay with fluorescein [4]. Black beans can enhance the body's immune system to recognize and destroy cancer cells, as well as inhibiting the development of new blood vessels, with such angiogenesis being necessary for tumor development. Black beans also weaken the adhesiveness and invasiveness of cancer cells, thereby reducing their metastatic potentials [3].

Chronic excessive oxidative stress and inflammation are major risk factor for the development of cancer. By increasing the supply of anti-oxidant and anti-inflammatory nutrients, black beans can reduce the risk of a number of cancers, including breast and colon cancers [5]. The aim of the present study was to investigate the anticancer activity of black turtle bean extracts on the breast cancer cell lines, MCF-7 and MDA-MB231.

\section{Results}

\section{Effect of BTB extract on cell viability}

To explore the effects of BTB extract on MCF-7 and MDA-MB231 cells, the viability of cells was analysed by a MTT assay. After 24-72 h exposure, all treated groups showed a significant decrease in cell viability. The IC50 of the BTB extract was $50 \mu \mathrm{g} / \mathrm{ml}$ in MDA-MB231 after $48 \mathrm{~h}$, and $50 \mu \mathrm{g} / \mathrm{ml}$ in MCF-7 cells after $72 \mathrm{~h}$ treatment (Fig. 1). The MTT assay showed that BTB extract inhibits the viability of MCF-7 and MDA-MB231 cells in a dose $(50-500 \mu \mathrm{g} / \mathrm{ml}$ ) and time dependent manner (Fig. 1a, b).

\section{Phase contrast microscopy for morphological analysis}

The inhibitory effect of the BTB extract was also assessed by observing morphological changes in MCF-7 and MDA-MB231 cells, using phase-contrast microscopy. The results showed a significant decrease in the number of cells following the addition of BTB extract (50 and $100 \mu \mathrm{g} /$ $\mathrm{ml}$ ), versus untreated cells. Furthermore, BTB extract induced morphological changes in treated cell, including cell shrinkage, membrane blebbing, cell rounding and decreased volume. However, no changes were observed in the case of normal cells (Fig. 2a). Morphological visualization with Giemsa staining showed BTB to induce apoptosis in breast cancer cell lines, as indicated by characteristic features of apoptosis, such as cell shrinkage, membrane blebbing, membrane disruption, broken nuclei and apoptotic body formations, as seen in Fig. $2 \mathrm{~b}$.

\section{Cell death assay Hoechst 33342 staining}

Hoechst 33342 staining indicated apoptotic cells to have shrunken, condensed and fragmented nuclei after exposure of BTB extract for $48 \mathrm{~h}$ [Fig. 2c (ii, iii, v, vi)]. This contrasts with the untreated non-apoptotic cells, which showed a low fluorescence, smooth, flattened nuclear morphology and normal nuclei, as well as uniformly dispersed chromatin [Fig. 2c (i, ii)].

\section{Propidium iodide (PI) staining}

Treated cells exhibited typical features of apoptosis, such as nuclei condensation, fragmentation into segregated bodies, and the formation of apoptotic bodies. The apoptotic nuclei clearly showed highly condensed or fragmented chromatin with apoptotic nuclei that were uniformly fluorescent after treatment with BTB $50 \mu \mathrm{g} / \mathrm{ml}$ [Fig. 2d (iii, v)] and $100 \mu \mathrm{g} /$ $\mathrm{ml}$ [Fig. 2d (iv, vi)]. Untreated cells were regular and intact, with nuclei exhibiting less bright red fluorescence staining [Fig. 2d (i, ii)]. Measurement of cell death using PI (Propidium iodide) demonstrated that BTB extract caused the cell death of $42.9 \%(50 \mu \mathrm{g} / \mathrm{ml})$ and $78.9 \%(100 \mu \mathrm{g} / \mathrm{ml})$, compared to MCF-7 control cells, and $55 \%(50 \mu \mathrm{g} / \mathrm{ml})$ and $74.7 \%(100 \mu \mathrm{g} / \mathrm{ml})$ compared to MDA-MB231 cells. Thus, BTB induces the cell death in breast cancer lines in a dosedependent manner (Additional file 1: Figure S1).
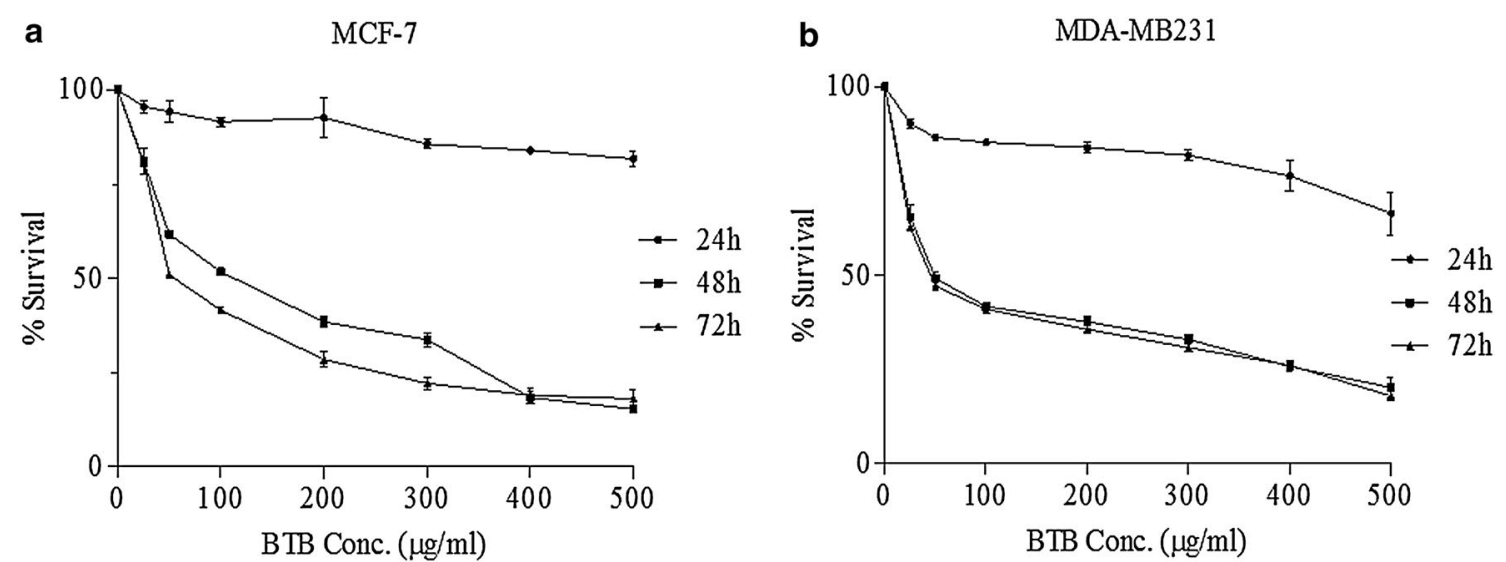

Fig. 1 Dose-response curve showing \% viability of MCF-7 (a) and MDA-MB231(b) cells at 0-500 $\mu \mathrm{g} / \mathrm{ml}$ concentrations of BTB extract for three different time points $\left(24,48\right.$ and $72 \mathrm{~h}$ ). $I C_{50}$ was found to be $50 \mu \mathrm{g} / \mathrm{ml}$ in MDA-MB231 after $48 \mathrm{~h}$ while in the case of MCF-7 cells it was $50 \mu \mathrm{g} / \mathrm{ml}$ after $72 \mathrm{~h}$ 

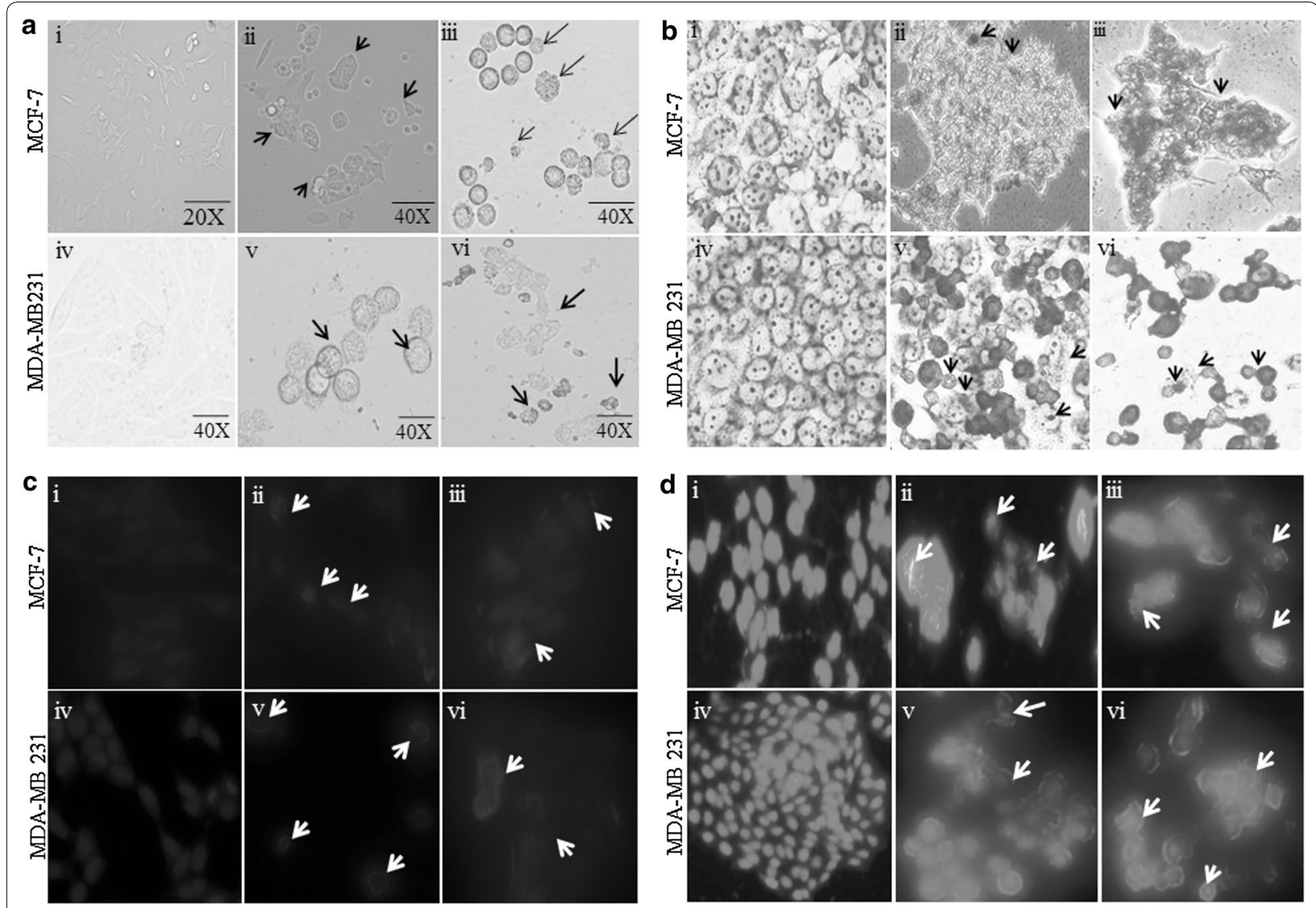

$40 \mathrm{X}$

Fig. 2 Morphological study of apoptosis in MCF-7 and MDA-MB231 induced by BTB: a by phase contrast microscopy (optical): (i, ii) untreated

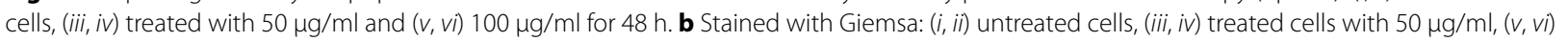
treated with $100 \mu \mathrm{g} / \mathrm{ml}$ for $48 \mathrm{~h}$. c Stained with Hoechst 33342: (i, ii) treated with $50 \mu \mathrm{g} / \mathrm{ml}$ and (iii, iv) $100 \mu \mathrm{g} / \mathrm{ml}$ for 48 h. d Stained with propidium iodide: (i, ii) untreated cells, (iii, iv) treated with $50 \mu \mathrm{g} / \mathrm{ml}$ and $(v, v i) 100 \mu \mathrm{g} / \mathrm{ml}$ for $48 \mathrm{~h}$ as shown by arrows

\section{Effect of BTB extract on cell cycle}

Cell cycle analysis, after $48 \mathrm{~h}$ treatment with BTB extract, showed a significant increase in the percentage of cells in the sub-G1 fraction, indicating apoptotic cell formation in both treated cell lines. Data also showed an enrichment of the $S$ phase in both types of cells, as compared to untreated cells. Interestingly, MDA-MB231 cells treated with BTB extract $(100 \mu \mathrm{g} / \mathrm{ml})$ showed an increase in the G2/M phase, while $S$ phase cell populations remained constant, versus untreated cells (Fig. 3). Thus, BTB extract caused $S$ and $G 2 / M$ phase cell cycle arrest in human breast cancer cells.

\section{BTB induced apoptosis in MCF-7 and MDA-MB-231 cells}

The apoptosis marker, phosphatidylserine exposure, was examined by the Annexin V-FITC/PI assay using flow cytometry, in order to further investigate the apoptotic inducing capacity of BTB extract in breast cancer cell lines. BTB induced apoptosis in MCF-7 and MDAMB-231 cells in a dose-dependent manner. The percentage of apoptotic cells following $50 \mu \mathrm{g} / \mathrm{ml}$ for $48 \mathrm{~h}$ was 15.97 and $60.7 \%$ MCF-7 and MDA-MB231 cells; following $100 \mu \mathrm{g} / \mathrm{ml}$ for $48 \mathrm{~h}$, the percentage of apoptotic cells was 94.47 , and $70.34 \%$, respectively; versus 0.07 and $5.21 \%$ respectively in untreated cells. Such data indicate that cell death occurred primarily through apoptosis, following treatment with BTB extract (Fig. 4a).

\section{Caspase $3 / 7$ assay}

To examine the molecular mechanism underlying the apoptosis process, cells were stained with aminoluciferinlabeled substrate of caspase. Cell lysates were prepared and incubated with Ac-DEVD-pNA (caspase-3/7). The reaction end products (Relative luminescence expression) were measured after $2 \mathrm{~h}$ incubation, as an indicant of caspase 3/7 enzyme activity. As shown in Fig. 4b, a 

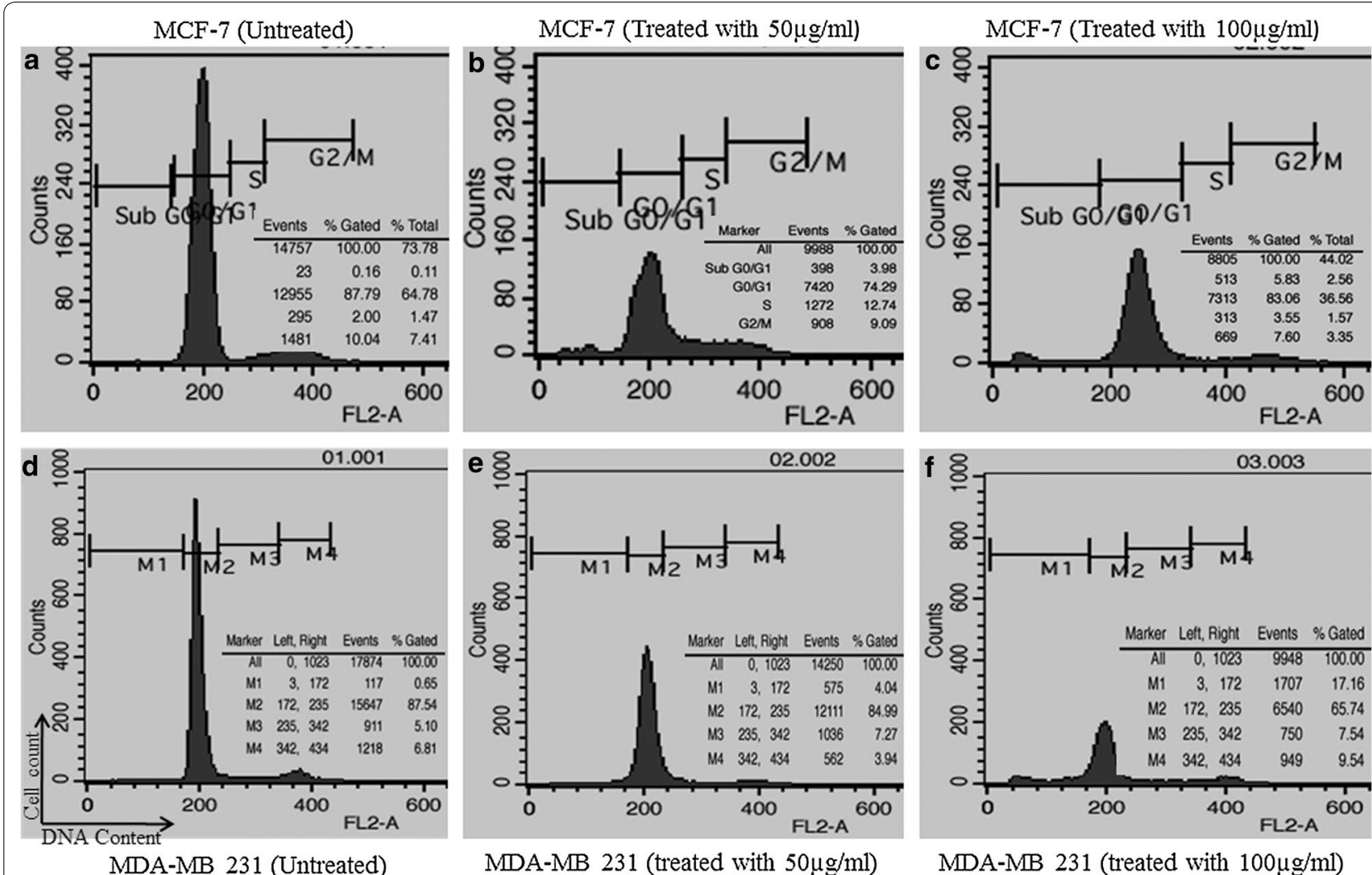

Fig. 3 Representative histograms depicting cell cycle distribution in MDA-MB-231 and MCF-7 cultures following $48 \mathrm{~h}$ treatment with 50 and $100 \mathrm{\mu g} / \mathrm{ml}$ concentrations of BTB extract caused S and G2/M phase cell cycle arrest in MCF-7cells $(\mathbf{b}, \mathbf{c})$ and MDA-MB231 cells (e, f) with comparison to untreated control cells $(\mathbf{a}, \mathbf{d})$

gradual increase of caspase-3/7 activity was observed in both MCF-7 and MDA-MB-231 cells treated with 50 and $100 \mu \mathrm{g} / \mathrm{ml}$ of BTB extract, as compared to untreated cells (Fig. 4b). Such data indicate that BTB extract induces activation of the intrinsic caspase pathway in both breast cancer cell lines.

\section{Effect of BTB on mitochondrial membrane potential}

To evaluate the functional status of mitochondria, the mitochondrial membrane potential was measured by staining with $10 \mu \mathrm{g} / \mathrm{ml}$ Rh123 dye, after treatment with BTB extract. After $24 \mathrm{~h}$ exposure, mitochondrial membrane potential was significantly decreased in BTBtreated MCF-7 and MDA-MB231 cells (25, 50, 100, 150, $200 \mu \mathrm{g} / \mathrm{ml}$ ) (Fig. 5). Such data suggest that mitochondrial dependent mechanism contributed to BTB extract mediated apoptosis in breast cancer cells. BTB extract dose-dependently induced mitochondrial membrane depolarization, as characterized by decrease of mitochondrial membrane potential (Fig. 5).

\section{Transmission electron microscopy}

Transmission electron microscopy (TEM) showed the integrity of cell membranes and many normal mitochondria in the MCF-7 and MDA-MB231 cells treated with BTB extract (Fig. 6A, D). Vacuole formation, dispersed chromatin, apoptotic body formation, autophagic vesicles, membrane blebbing, condensed mitochondria formation, and swollen mitochondria were noted in the BTB treated cells (Fig. 6B, C, E, F). Such data indicate that BTB extract resulted in ultrastructural damage, as well as inducing autophagy in MCF-7 and MDA-MB231 cells.

\section{Apoptosis confirmation by DNA fragmentation}

To gain further insights into the mode of cell death caused by BTB extract, its effect on the DNA fragmentation which is generally used for the detection of apoptosis, was investigated. DNA fragmentation analysis of BTB-treated cells showed a laddering pattern, which is characteristic of apoptosis, indicating internucleosomal DNA degradation (Fig. 7). 


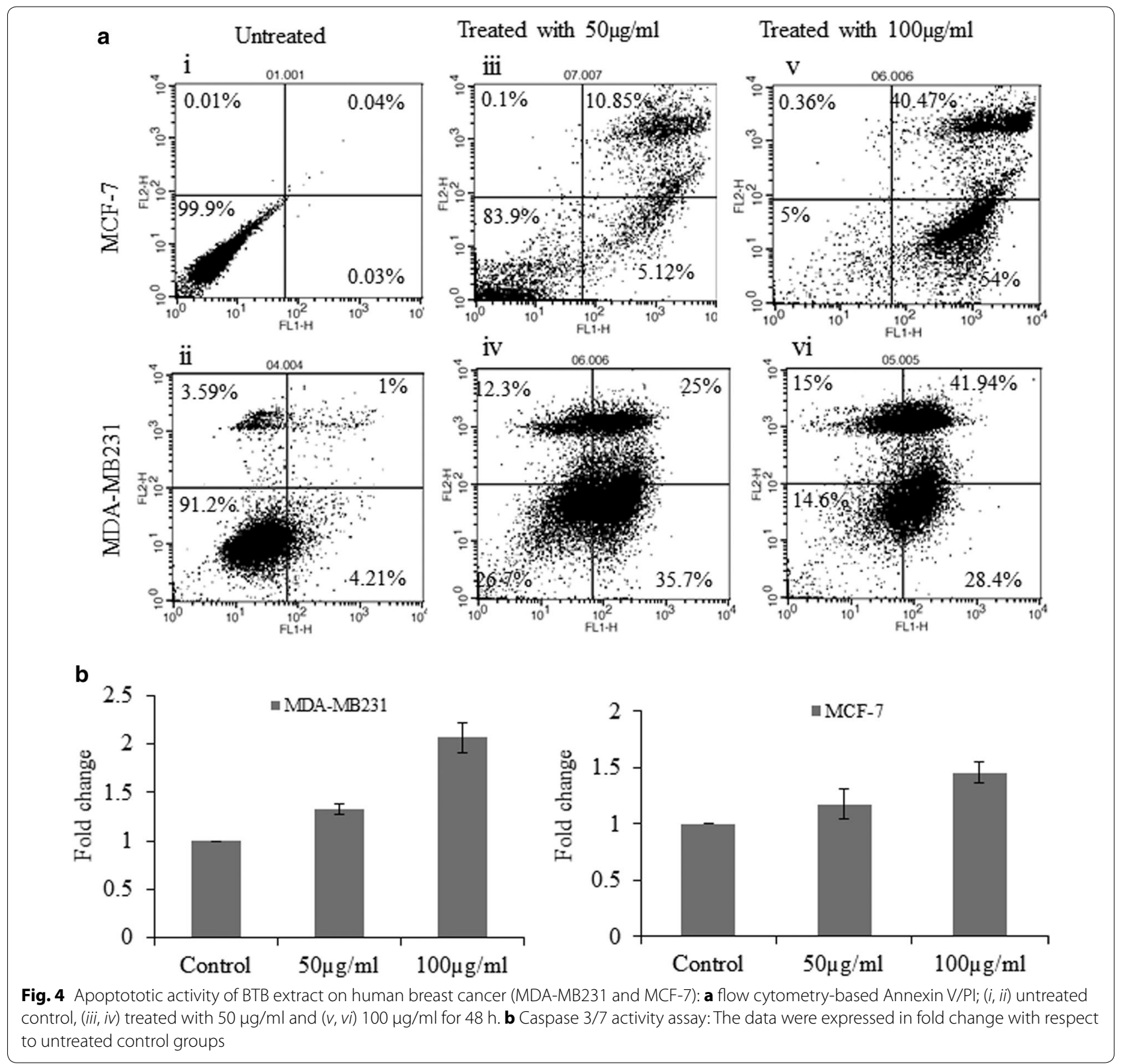

Effect of BTB on BCl-2, Bax and BCl-xL expressions

The effect of BTB extract on the expression levels of Bcl2, Bcl-xL, and Bax genes, by RT-PCR and qRT-PCR and the clear band of amplified products, was investigated (Fig. 8a). BTB extract altered the Bcl-2, Bcl-xL, Bax gene expression after $24 \mathrm{~h}$ treatment in MCF-7 and MDAMB231 cells, in a dose dependent manner [Fig. 8b (i, iii)]. Compared to untreated cells, Bax levels were markedly increased, in a dose-dependent manner [Fig. 8b (ii)]. However, the expression of $\mathrm{Bcl}-2$ was decreased, as BTB extract concentration was increased [Fig. 8b (iii)]. The result suggested that $\mathrm{BTB}$ extract induced the change in the expression of Bcl-2 family proteins, increasing pro-apoptotic Bax and decreasing anti-apoptotic Bcl-2, thereby increasing the likelyhood of apoptosis in breast cancer cell lines.

\section{Discussion}

Breast cancer is the most prominent cancer in women across India. According to GLOBOCAN [6], for the year 2012, an estimated 70,218 women died in India during 2012 due to breast cancer. This is higher than any other country in the world. Thus, the extracts of bioactive plants, with their known beneficial and remedial effect, 


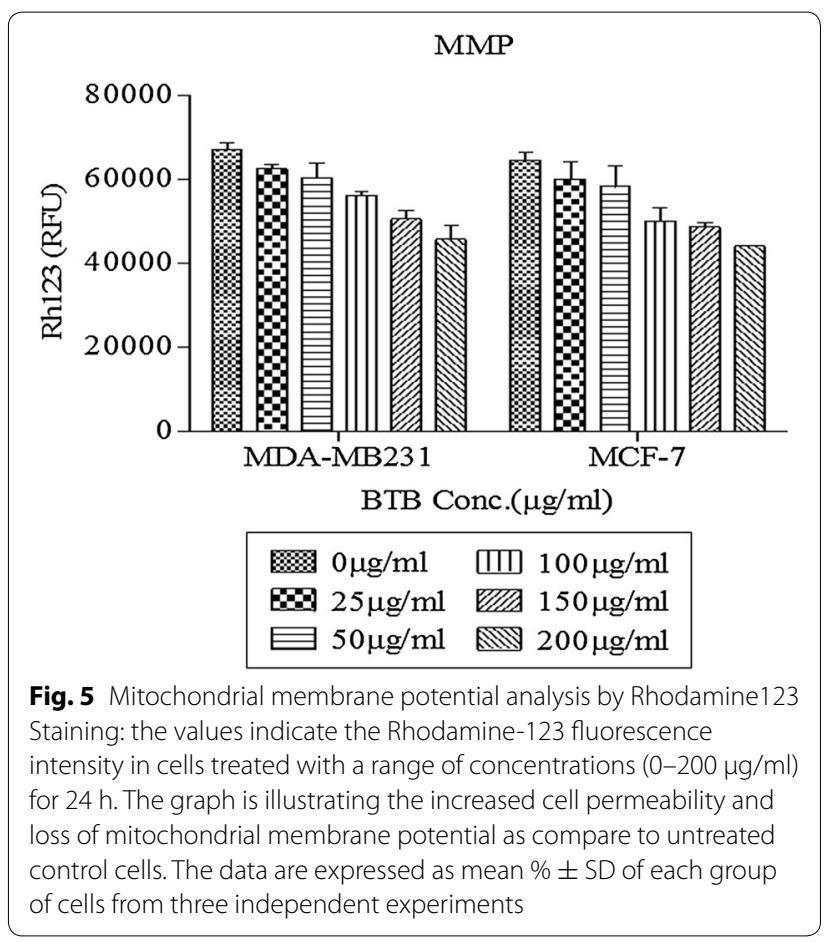

is an important area of investigatation for anti-breast cancer agents. The present study explored the anticancer activity of BTB extract on human breast cancer cell lines, and the different mechanism underpinning this. To date, no study has reported the cytotoxic effect of BTB (Phaseolus vulgaris) extract in human breast cancer cell lines. Therefore, antiproliferative and apoptotic effects of BTB extract on MCF-7 and MDA-MB-231 cells were investigated in the present study. BTB extract induced a strong cytotoxic effect on MCF-7 and MDAMB231 cells, in a dose dependent manner with an $\mathrm{IC}_{50}$ of $50 \mu \mathrm{g} / \mathrm{ml}$ after $48-72 \mathrm{~h}$. Such data suggests that BTB extract inhibits the proliferation of different human breast cancer cells cell types, including estrogen receptor negative (MDA-MB231) and estrogen receptor positive (MCF-7) breast cancer lines. BTB extract induced morphological changes in breast cancer cell lines, including cell shrinkage, membrane blebbing, and cell rounding, versus untreated cells under phase-contrast microscopy and Giemsa staining. Further, BTB extract induced apoptosis in human breast cancer cell lines, as detected by Hoechst 33342 and PI nuclear staining
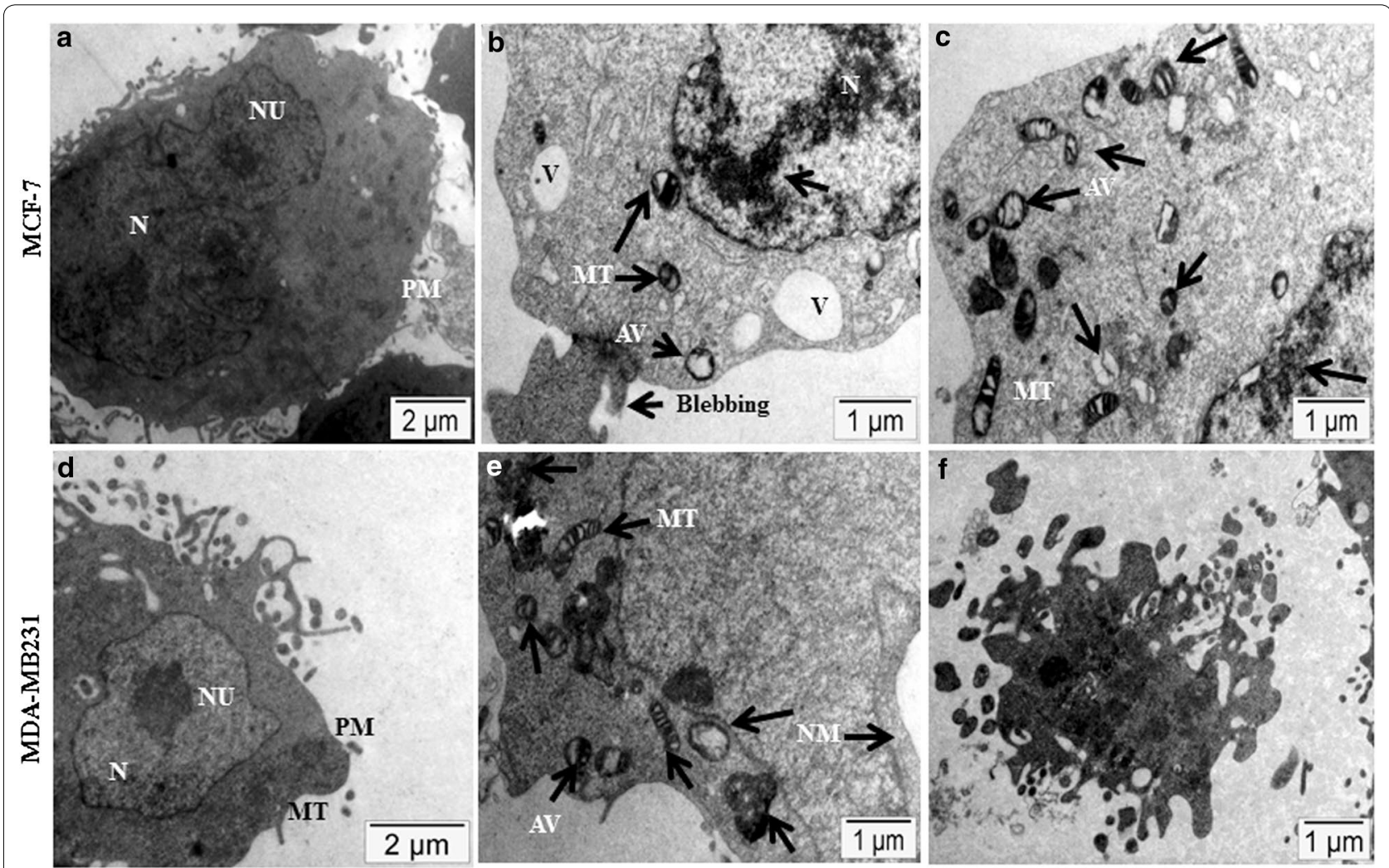

Fig. 6 Ultrastructural features of cell death: an 48 h exposure of MCF-7 and MDA-MB231 cell lines in BTB extract in resulted in vacuole and condensed mitochondria formation, dispersed chromatin, apoptotic body formation, autophagic vesicles and membrane blebbing (B, C, E, F) with comparison to untreated control (A, D). Arrows indicate: N nucleus, NU nucleolus, PM plasma membrane, MT mitochondria, $V$ vacuole, AV autophagic vesicle 


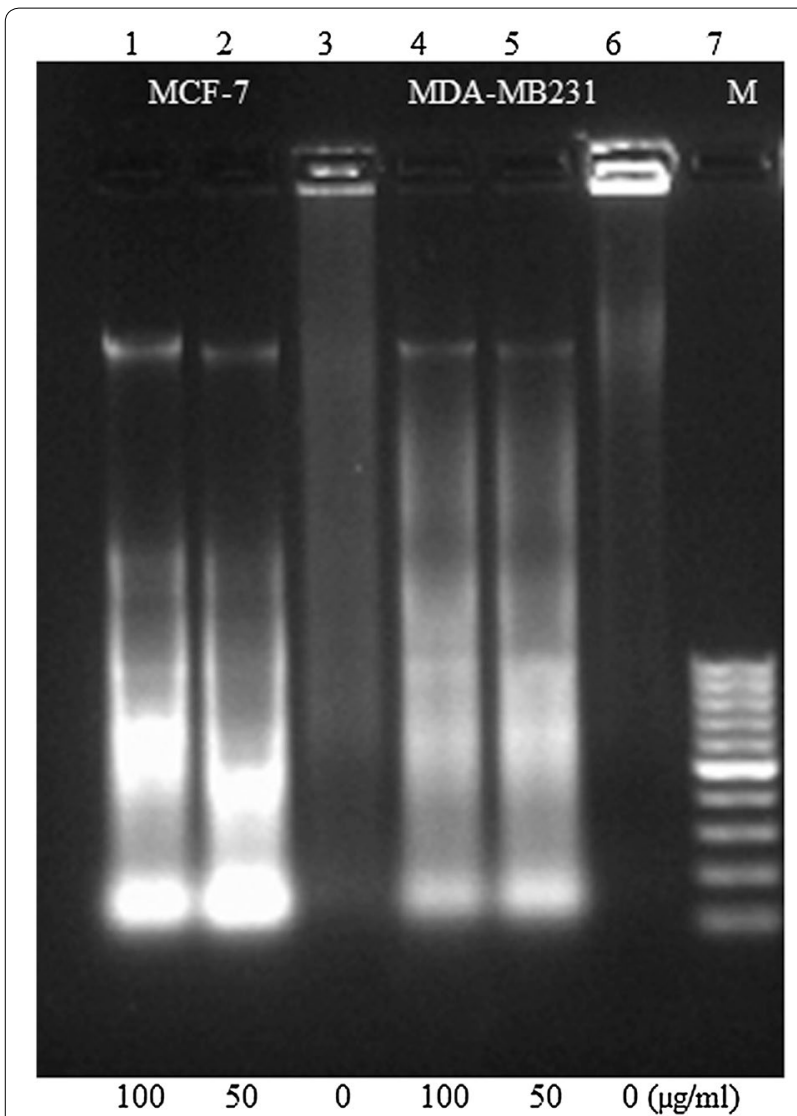

Fig. 7 DNA fragmentation assay: Lane 1 treated with $100 \mu \mathrm{g} / \mathrm{ml} ; 2$ treated with $50 \mu \mathrm{g} / \mathrm{ml} ; 3 \mathrm{MCF}-7$ (untreated); 4 MDA-MB231 treated with $100 \mu \mathrm{g} / \mathrm{ml} ; 5$ treated with $50 \mu \mathrm{g} / \mathrm{ml}$; 6 untreated; and $7100 \mathrm{bp}$ DNA ladder

after $48 \mathrm{~h}$ treatment, and also evident under fluorescent microscopy. The treated cells showed features of apoptosis such as nuclei condensation and fragmentation into segregated bodies, as well as the formation of apoptotic bodies [7].

In this study, the protein levels of caspase-3/7 were increased in breast cancer cell lines, after exposure to BTB extract. This is one mechanism by which BTB extract may contribute to the inhibition of breast carcinogenesis. Alterations in the mitochondrial membrane potential are important to the release of cytochrome c, leading to the activation of caspase cascade and subsequent cell death [8]. The loss of mitochondrial membrane potential has been considered as a critical stage in the mitochondria-mediated apoptotic pathway [9]. Our study revealed that $\mathrm{BTB}$ extract induced a dose-dependent depolarization of the mitochondrial membrane potential, as evidenced by the rhodamine 231 assay. Consequently, the formation of mitochondrial permeability transition pore, leading to the leakage of apoptogenic proteins, such as cytochrome $\mathrm{c}$ and apoptosis-inducing factor, results in caspase-dependent cell death. DNA fragmentation analysis showed that BTB extract induced DNA fragmentation in both MCF-7 and MDA-MB231 cells.

The apoptosis ratio and cell cycle arrest were analysed by flow cytometry, with different concentrations in MCF-7 and MDA-MB-231 cells. BTB extract induced cell cycle arrest in the $S$ and G2/M phases in MCF-7 and MDA-MB231 cells. Flow cytometry analysis for apoptosis supported the cytological results, with a significant increase in Annexin-V binding following BTB extract treatment in MCF-7 and MDA-MB231 cell lines, versus untreated cells. We further provide morphological evidence in support of apoptotic pathway induction by using TEM, which morphologically discriminates the apoptotic or necrotic cell death pathways [10]. The ultrastructural analysis was also performed on MCF-7 and MDA-MB231 cells exposed to BTB extract treatments. This data again indicated the inhibitory effect of BTB extract on both cell lines with vacuole formation, condensed mitochondria formation, dispersed chromatin, apoptotic body formation, autophagic vesicles and membrane blebbing evident, as compare to untreated cells.

It is well established that Bax is positively regulated by p53 protein, and negatively controls Bcl-2 expression [11]. Apoptosis is a well-controlled process, which involves changes in the expression of an array of genes [12]. Bcl-2 family proteins have an important role in regulating cell apoptosis [13]. Over-expression of pro-apoptotic molecules, such as Bax, can accelerate cell apoptosis [14]. The inhibition of Bcl-xL and Bcl-2 expression, and their antiapoptotic functions, can help to increase the efficiency of chemotherapeutic agents. The current investigation found that BTB extract treatment significantly increased the expression of Bax and decreased the expression of Bcl-2, and $\mathrm{Bcl}-\mathrm{xL}$, in a dose dependent manner in both MCF-7 and MDA-MB-231 cell lines. It is therefore clear that BTB extract induces apoptosis in MCF-7 and MDA-MB-231 cells, through intrinsic and extrinsic pathways. Overall, the present study shows the cytotoxic effects of BTB extract, especially on cell growth and apoptosis, in MCF-7 and MDA-MB231 breast cancer cell lines. This is the first report of BTB extract-induced breast cancer cell toxicity and programmed cell death via the apoptosis pathway in MCF-7 and MDA-MB231 breast cancer cell lines. Such data indicates that BTB extract may have therapeutic potential in the management of breast cancer. However, further investigation is required to further elucidate the molecular mechanisms underpinning BTB extract utility in the regulation of breast cancers. 


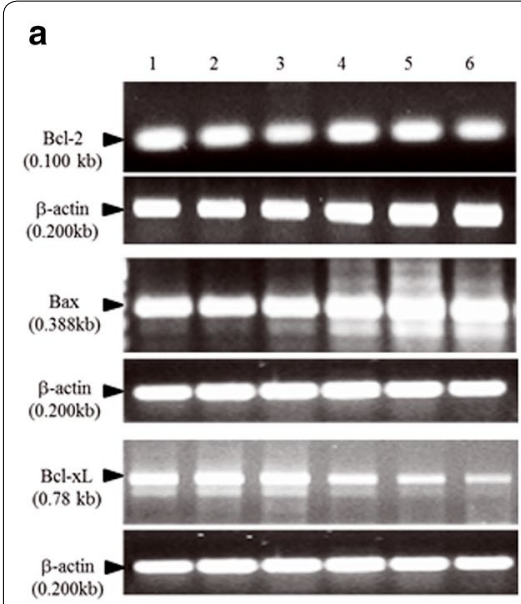

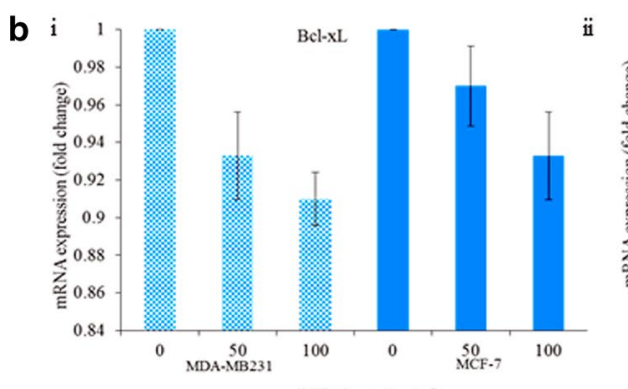

iii
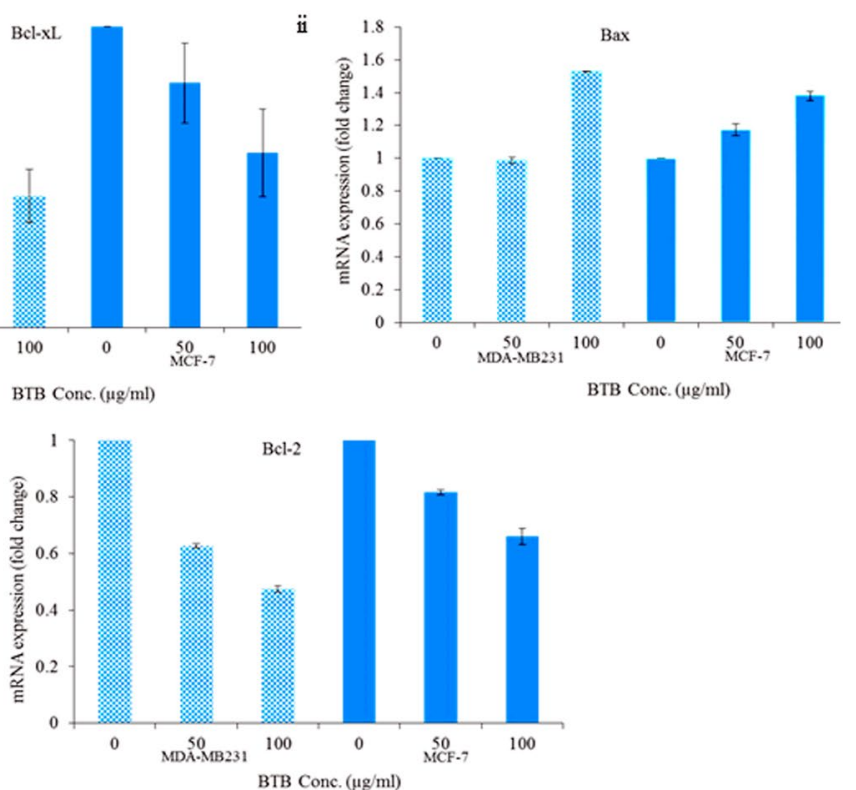

Fig. 8 Effect of BTB extracts on BCl-2, Bax and BCl-xL in MCF-7 and MDA-MB231 cells (a) on genes (mRNA) expression by PCR in MCF-7: Iane 1 (untreated); lane 2 and 3 treated with 50 and $100 \mu \mathrm{g} / \mathrm{ml}$ respectively. MDA-MB231: lane 4 (untreated); lane 5 and 6 treated with 50 and $100 \mu \mathrm{g} / \mathrm{ml}$ respectively. $\mathbf{b}$ On mRNA expression by real time PCR of intrinsic apoptotic signalling molecules on cells; change in the expression of Bcl-xL (i) and Bax (ii) genes in both breast cancer cells in a dose dependent manner, (iii) Bcl-2 was decreased with the increasing concentration of BTB extract

\section{Methods}

Preparation of plant extracts from Phaseolus vulgaris seeds The seeds of black turtle bean (BTB) were purchased from Gandhiana Organic Farmers' Self Help Group (Maharashtra, India, www.gandhiana.org). Black Turtle Variety of Phaseolus vulgaris L. beans with Ref. No. NISCAIR/RHMD/Consult/2016/2991-18 was identified and deposited in the Raw Material Herbarium and Museum, (RHMD) NISCAIR, New Delhi, India. The seeds (60 g) were kept for swelling in $10 \mathrm{mM}$ Tris-Cl buffer ( $\mathrm{pH} 7.5$ ) overnight and grinder homogenized in the same buffer. Insoluble fractions were filtered by cheese clothes and centrifuged at $13,000 \times g$ at $4{ }^{\circ} \mathrm{C}$ for $30 \mathrm{~min}$. Before being subjected to cell culture treatments, the required concentration of crude extract named as BTB extract, was dissolved in the cell culture medium (DMEM) and filtered through $0.22 \mu \mathrm{m}$ filter.

\section{Cell viability assay}

To determine the effects of BTB extract on the viability of MCF-7 and MDA-MB-231 cells, an MTT assay was carried out. Cancer cells were incubated with different concentrations of extracts ranging from 25 to $500 \mu \mathrm{g} / \mathrm{ml}$ for $24-72 \mathrm{~h}$. After the completion of the treatment time, $10 \mu \mathrm{l}$ of $5 \mathrm{mg} / \mathrm{ml} \mathrm{MTT}$ was added to wells and incubated for $4 \mathrm{~h}$ at $37{ }^{\circ} \mathrm{C}$. Then the treatment medium was removed and $100 \mu \mathrm{l}$ of dimethyl sulfoxide (DMSO) was added to each well to dissolve the formazan complex. The amount of colored formazan was determined by its absorbance at $570 \mathrm{~nm}$ in a BioTek ELISA Microplate Reader (BioTek Instrument, Inc., Winooski, VT, USA). The experiments were performed in triplicates.

\section{Morphological assessment of apoptotic cells}

Morphological changes in MCF-7 and MDA-MB231 cells, treated with 50 and $100 \mu \mathrm{g} / \mathrm{ml}$ concentrations of BTB extract for $48 \mathrm{~h}$, were observed under inverted contrast microscope (Nikon H600L microscope; Nikon, Japan) with suitable filter $20 \times$ and $40 \times$ magnifications consecutively. The morphological changes in the cells were also examined by staining with Giemsa (Merck, USA) for $10 \mathrm{~min}$ and observed under the phase contrast microscope (Nikon H600L microscope), as detailed by Chih et al. [15].

\section{Cell death assay}

MCF-7 and MDA-MB231 cells were treated with BTB extract, at concentrations of 50 and $100 \mu \mathrm{g} / \mathrm{ml}$. The cells were collected, washed by PBS and allowed to dry in situ after $48 \mathrm{~h}$ of treatment. Genomic DNA was stained with DNA-specific fluorescent dye; Hoechst 33342 and PI $(10 \mu \mathrm{g} / \mathrm{ml})$ separately for $10 \mathrm{~min}$ at $37^{\circ} \mathrm{C}$. The images were recorded under a fluorescence microscope (Nikon H600L microscope; Nikon, Japan [16]. Dead cells were quantified by flow cytometry (BD FACS Diva $^{\mathrm{TM}}$ software). 


\section{Cell cycle analysis}

To determine the effect of BTB extract on relative cellular DNA content, cell cycle analysis was performed using propidium iodide (PI) staining via flow cytometry. Briefly, the breast cancer cells were seeded in 6-well plates at a density of $1 \times 10^{5}$ cells per well, and then treated with 50 and $100 \mu \mathrm{g} / \mathrm{ml}$ of BTB extract for $48 \mathrm{~h}$ and stained with PI $(10 \mu \mathrm{g} / \mathrm{ml} \mathrm{PI}, 200 \mu \mathrm{g} / \mathrm{ml}$ RNase $)$ for $15 \mathrm{~min}$ at room temperature in the dark. Untreated cells, as a negative control, were simultaneously measured. The hypodiploid DNA content of apoptotic cells were measured by quantifying the sub-G1 peak in the cell cycle pattern. The acquisition of 20,000 events per sample was recorded in a FACS Calibur (Becton-Dickinson) equipped with CELL Quest Pro software.

\section{Annexin V-FITC assay}

BTB extract-induced apoptosis in human breast cancer cells was determined by flow cytometry using the Annexin V-FITC conjugated apoptosis detection kit (BD Biosciences, San Diego, CA). Briefly, MCF-7 and MDA-MB-231 cells $\left(6 \times 10^{4}\right)$ were treated with different concentrations of BTB extract for $48 \mathrm{~h}$ followed by harvesting, washing with PBS, and incubation with the Annexin-V FITC (5 $\mu \mathrm{l})$ in binding buffer at room temperature for $15 \mathrm{~min}$ in the dark. $5 \mu \mathrm{l}$ of PI was added to the stained cells immediately prior to analysis, then analysed by the Cell Quest Pro software using flow cytometry (FACS Calibur, BD Bioscience).

\section{Caspase-3/7 activity assay}

Caspase activity was determined using Caspase-Glo ${ }^{\mathrm{TM}} 3 / 7$ Assay kit (Promega, Madison, WI). Cells were cultured in 96-well culture plates in $100 \mu \mathrm{l}$ of DMEM and treated with different concentrations of BTB extract. At the end of $24 \mathrm{~h}$ incubation, $100 \mu \mathrm{l}$ of assay reagent was added and incubated for $2 \mathrm{~h}$ at room temperature. Luminescence was measured using a Fluorescence/Multi-Detection Microplate Reader (Synergy2, BioTek Instrument, Inc., Winooski, USA).

\section{Measurement of mitochondrial membrane potential}

The change in mitochondrial membrane potential was measured using the rhodamine 123 probe (Rh123, Sigma-Aldrich Co. MO, USA). MCF-7 and MDA-MB231 cells were seeded in 24-well culture plates at a density of $5 \times 10^{4}$ cells/well and allowed to attach for $24 \mathrm{~h}$. The media was then replaced with an equal volume of fresh DMEM containing BTB extract $(25-200 \mu \mathrm{g} / \mathrm{ml})$. After $48 \mathrm{~h}$ exposure, cultures were incubated with Rh-123 $\left(10 \mu \mathrm{g} / \mathrm{ml}\right.$ in DMSO) at $37{ }^{\circ} \mathrm{C}$ for $30 \mathrm{~min}$. The change in mitochondrial membrane potential was determined using a Fluorescence/Multi-Detection Microplate Reader
(Synergy 2, BioTek Instrument, Inc., VT, USA) at $485 \mathrm{~nm}$ excitation wavelength and $528 \mathrm{~nm}$ emission wavelength. Each value represents mean \pm SD from triplicates.

\section{DNA fragmentation analysis}

To confirm the apoptotic mode of cell death, DNA fragmentation assay was performed. MCF-7 and MDAMB231 cells were treated with 50 and $100 \mu \mathrm{g} / \mathrm{ml}$ of BTB extract for $48 \mathrm{~h}$. The lysis buffer $(100 \mu \mathrm{l}$ of $100 \mathrm{mM}$ Tris $\mathrm{pH}-8.5,5 \mathrm{M} \mathrm{NaCl}, 0.5 \mathrm{M}$ EDTA, 0.05\% TritonX-100, $10 \mu \mathrm{g} / \mathrm{ml}$ proteinase $\mathrm{K}$ and $10 \%$ SDS) was added to the pellet and incubated for $30 \mathrm{~min}$ on ice. The supernatant was collected in a fresh tube and mixed with 25:24:1 mixture of phenol: chloroform: isoamyl alcohol then precipitated with two equivalents of ice cold ethanol plus one-tenth equivalent of sodium acetate. This was followed by centrifugation at $12,000 \times g$ for $20 \mathrm{~min}$. The pellet was re-suspended in $30 \mu \mathrm{l}$ of sterile water-RNase solution $(15 \mu \mathrm{g} / \mathrm{ml}$ RNase in sterile water $)$ and subjected to electrophoresis in TE buffer (10 mM Tris-HCI, $1 \mathrm{mM}$ EDTA, $\mathrm{pH}$ 8.0) on a $1 \%$ agarose gel and imaged in a Molecular Imager (Gel DocTM XR+) (BioRad, Hercules, USA).

\section{RNA isolation and quantitative RT-PCR}

Total RNA was extracted using Ribozol reagent (AMRESCO, USA) from both untreated and treated breast cancer cells with BTB extract (50 and $100 \mu \mathrm{g} / \mathrm{ml}$ ), after $24 \mathrm{~h}$ incubation according to the manufacturer's instructions. $1 \mu \mathrm{g}$ RNA was then reversed transcribed into cDNA in a $20 \mu \mathrm{l}$ reaction solution containing $5 \mathrm{X}$ Reaction Buffer, RNase Inhibitor $(20 \mathrm{U} / \mu \mathrm{l}), 10 \mathrm{mM}$ deoxyribonucleotide triphosphate (dNTP) Mix, $1 \mu \mathrm{l}$ random hexamer primer and $1 \mu \mathrm{l}(200 \mathrm{U} / \mu \mathrm{l})$ of MuLV reverse transcriptase (Fermentas, USA) by thermal cycler (BioRad, Hercules, CA). Expression of three tumor related genes namely, $\mathrm{Bcl}-2, \mathrm{Bax}$, and $\mathrm{Bcl}-\mathrm{xL}$ were studied using these cDNA as template for PCR. $\beta$-Actin was used as a control. The following oilgonucleotide primers (IDT, India) were used in the real-time qRT-PCR analysis (Table 1). Amplifications were performed in a gradient thermal cycler.

The cycling condition of the initial PCR was an activation step of $3 \mathrm{~min}$ at $95{ }^{\circ} \mathrm{C}$, followed by 30 cycles of $95{ }^{\circ} \mathrm{C} / 1 \mathrm{~min}, 72{ }^{\circ} \mathrm{C} / 1 \mathrm{~min}$ and a final extension of $72{ }^{\circ} \mathrm{C} / 10 \mathrm{~min}$, for $\beta$-actin and Bcl-2 family gene. The annealing temperature of $\mathrm{Bcl}-2$, Bax and $\mathrm{Bcl}-\mathrm{xL}$ were 60.4, 60 and $58.4{ }^{\circ} \mathrm{C}$, respectively. After amplification, all the PCR reactions were analysed in $1.0 \%$ agarose gel and visualized by ethidium bromide staining under UV irradiation. Gene Rular 100 bp DNA ladder (Fermentas, USA) was used as a DNA marker. Bcl-2, Bax, Bcl-xL, and $\beta$-actin mRNA expression were measured by quantitative 
Table 1 List of specific primers for apoptotic genes and control

\begin{tabular}{lll}
\hline Gene & Primers & $\begin{array}{l}\text { Amplification } \\
\text { product (bps) }\end{array}$ \\
\hline BCl-2 & F 5'-TGTGTGGAGAGCGTCAACC-3' & 100 \\
& R 5'-TGGATCCAGGTGTGCAGGT-3' & \\
Bax & F 5'-GATGCGTCCACCAAGAAGC-3', & 388 \\
& R 5'AAGTCCAATGTCCAGCCCAT-3' & \\
BCl-xL & F 5'-TTGGACAATGGACTGGTTGA-3' & 780 \\
& R 5'-GTAGAGTGGATGGTCAGTG-3' & \\
B-actin & F 5'-TGGCACCCAGCACAATGAA-3' & 200 \\
& R 5'-CTAAGTCATAGTCCGCCTAGAAGCA-3' & \\
\hline
\end{tabular}

real-time RT-PCR in an MX3005p PCR system (Stratagene, Europe). Reaction was performed using MESA Green PCR master mix containing SYBR green dye. The specificity of the amplification product was determined by melting curve analysis for each primer pairs. The data was analysed by comparative CT method and the fold change was calculated by $2^{-\Delta \Delta C T}$ method described by Livak [17].

\section{Transmission electron microscopy}

Transmission electron microscopy (TEM) was performed to identify mitochondrial morphological changes and autophagy in the MCF-7 and MDA-MB231 cell lines treated with BTB extract for $48 \mathrm{~h}$. The samples were passed through propylene oxide and infiltrated in epoxy resin overnight and cured at $60{ }^{\circ} \mathrm{C}$ for $72 \mathrm{~h}$. Ultracut Reichert Jung-Austria microtome was used to obtain golden color sections, thereafter stained with $2 \%$ uranyl acetate and Reynold's lead citrate. The obtained sections were observed under a Morgagni-268 electron microscope under standard operating conditions.

\section{Statistical analysis}

All the data are expressed as mean $\pm \mathrm{SD}$. The significance levels for comparison of differences were determined with a one way ANOVA, followed by Bonferroni and Dunnet post hoc tests for multiple comparisons (GraphPad Software, USA) and P $<0.05$ was considered statistically significant when compared to control.

\section{Additional file}

Additional file 1: Figure S1. PI staining assay showing the dead cells when treated with BTB extract (50 and $100 \mu \mathrm{g} / \mathrm{ml}$ ) in MCF-7 and MDAMB231 cells, respectively.

\section{Authors' contributions}

SK conducted major part of the experiment, VKS assisted in PI staining experiment, SY assisted in analysing the data of cell viability, SD wrote the manuscript and provided the chemicals. All authors read and approved the final manuscript.
Acknowledgements

Authors acknowledge Indian Council of Medical Research (ICMR), Government of India, for research scholarship (I-774)

\section{Competing interests}

The authors declare that they have no competing interests.

\section{Publisher's Note}

Springer Nature remains neutral with regard to jurisdictional claims in published maps and institutional affiliations.

Received: 28 November 2016 Accepted: 31 May 2017

Published online: 20 June 2017

\section{References}

1. Ligresti G, Libra M, Militello L, Clementi S, Donia M, Imbesi R, Malaponte G, Cappellani A, McCubrey JA, Stivala F (2008) Breast cancer: molecular basis and therapeutic strategies (Review). Mol Med Rep 1:451-458

2. Desai AG, Qazi GN, Ganju RK, El-Tamer M, Singh J, Saxena AK, Bedi YS, Taneja SC, Bhat HK (2008) Medicinal plants and cancer chemoprevention. Curr Drug Metab 9:581-591

3. Newman DJ, Cragg GM (2007) Natural products as sources of new drugs over the last 25 years. J Nat Prod 70:461-477

4. Wahle KW, Brown I, Rotondo D, Heys SD (2010) Plant phenolics in the prevention and treatment of cancer. Adv Exp Med Biol 698:36-51

5. Xu BJ, Chang SK (2008) Total phenolic content and antioxidant properties of eclipse black beans (Phaseolus vulgaris L.) as affected by processing methods. J Food Sci 73:H19-H27

6. Ferlay J, Soerjomataram I, Ervik M, Dikshit R, Eser S, Mathers, Rebelo CM, Parkin DM, Forman D, Bray F (2013) GLOBOCAN 2012 v1.0, Cancer Incidence and Mortality Worldwide: IARC Cancer Base No. 11 [Internet]. Lyon, International Agency for Research on Cancer. http://globocan.iarc

7. Moongkarndi P, Kosem N, Kaslungka S, Luanratana O, Pongpan N, Neungton N (2004) Antiproliferation, antioxidation and induction of apoptosis by Garcinia mangostana (mangosteen) on SKBR3 human breast cancer cell line. J Ethnopharmacol 90:161-166

8. Riedl SJ, Shi Y (2004) Molecular mechanisms of caspase regulation during apoptosis. Nat Rev Mol Cell Biol 5:897-907

9. Crompton M (1999) The mitochondrial permeability transition pore and its role in cell death. Biochem J 341(Pt 2):233-249

10. Kamba AS, Ismail M, Ibrahim TA, Zakaria ZA, Gusau LH (2014) In vitro ultrastructural changes of MCF-7 for metastasise bone cancer and induction of apoptosis via mitochondrial cytochrome $\mathrm{C}$ released by $\mathrm{CaCO}_{3} / \mathrm{Dox}$ nanocrystals. Biomed Res Int 2014:391869

11. Miyashita T, Krajewski S, Krajewska M, Wang HG, Lin HK, Liebermann DA, Hoffman B, Reed JC (1994) Tumor suppressor p53 is a regulator of bcl-2 and bax gene expression in vitro and in vivo. Oncogene 9:1799-1805

12. Nakagawa H, Tsuta K, Kiuchi K, Senzaki H, Tanaka K, Hioki K, Tsubura A (2001) Growth inhibitory effects of diallyldisulfide on human breast cancer cell lines. Carcinogenesis 22:891-897

13. Burlacu A (2003) Regulation of apoptosis by Bcl-2 family proteins. J Cell Mol Med 7:249-257

14. Allen RT, Cluck MW, Agrawal DK (1998) Mechanisms controlling cellular suicide: role of Bcl-2 and caspases. Cell Mol Life Sci 54:427-445

15. Chih HW, Chiu HF, Tang KS, Chang FR, Wu YC (2001) Bullatacin, a potent antitumour annonaceous acetogenin, inhibits proliferation of human hepatocarcinoma cell line 2.2 .15 by apoptosis induction. Life Sci 69:1321-1331

16. Zhang Y, Zhang J, Dai B, Wang N, He L (2011) Anti-proliferative and apoptotic effects of the novel taspine derivative tas41 in the Caco-2 cell line. Environ Toxicol Pharmacol 31:406-415

17. Livak KJ, Schmittgen TD (2001) Analysis of relative gene expression data using real-time quantitative PCR and the 2(-Delta Delta C(T)) Method. Methods 25:402-408 